\title{
Integrated Management of Greenhouse Crops-A Conceptual and Potentially Practical Model
}

\author{
N.D. Clarke \\ AI Solutions, 47 Tomlin Center, Richmond Hill, Ont. L4C 7T1, Canada \\ J.L. Shipp ${ }^{1}$, W.R. Jarvis, A.P. Papadopoulos, and T.J. Jewett \\ Agriculture Canada, Research Station, Harrow, Ont. NOR 1G0, Canada
}

The management of greenhouse crops is technologically advanced. Computerized environmental control and fertigation systems are already in wide commercial use. They offer opportunities for precise and versatile crop management, but new developments demand continued reappraisal of operations. Environmental regulations, fewer effective registered pesticides, worker health concerns, and consumer demand for safer food products are forcing the greenhouse industry to reduce its use of chemicals for controlling diseases and pests, while environmental concerns dictate economy in fertilizer and water use. Biological control agents and cultural control strategies are alternatives to chemical control of pests and diseases. Such agents are commercially available for all major insect and mite pests of greenhouse crops, but because of stringent health and safety requirements for biological fungicides and bactericides, few biological control agents for diseases are available commercially. Careful crop management and manipulation of the greenhouse environment also can decrease disease and pest incidence. Many growers have yet to adopt nonchemical approaches to greenhouse crop management, mainly because biological and environmental control methods are thought to be more difficult to manage, and possibly more expensive, than chemical control.

With chemical control strategies, pesticides are applied to the plants to kill the target pest or pathogen instantly. With biological and environmental control strategies, biological agents or environmental manipulation is used to keep the target pest or pathogen populations below economically damaging levels. The increased complexity arises because of the biological nature of the control strategy. Biological control is not instantaneous because some time is always required until the population density of the introduced agent reaches an effective level. Thus, early detection of pathogens and pests and timely introduction of biological control organisms are essential. Management strategies and conditions within the greenhouse must be such that they promote crop productivity, as well as the activity of biological control agents, while impeding the development of pests and dis-

Received for publication 12 Oct. 1993. Accepted for publication 14 Feb. 1994. The cost of publishing this paper was defrayed in part by the payment of page charges. Under postal regulations, this paper therefore must be hereby marked advertisement solely to indicate this fact.

${ }^{1}$ To whom reprint requests should be addressed. eases. This requires an integrated strategy to crop management that combines plant production and disease and pest management strategies into one common decision-making process (Shipp et al., 1991).

An expert system approach offers a solution to the problem of reconciling and manipulating the complex strategies for crop, disease, and pest management. An expert system is a computer program that mimics human experts in assisting people to diagnose problems, selects among alternatives, and plans and manages operational systems (Barrett and Jones, 1989). A typical expert system consists of a knowledge base, an inference engine that analyzes the knowledge base, and an end-user interface that accepts inputs and presents outputs. The knowledge base contains information and strategies, usually obtained from a human expert, for making complex and difficult decisions in a specific problem area. Having an expert system on a computer is similar to having an expert available for consultation $24 \mathrm{~h}$ a day.

Several expert systems have been developed for greenhouse applications. Gohler (1989) described a simple conceptual model of an expert system that provided advice on plant nutrition, temperature control, and pest control for greenhouse cucumber (Cucumis sativus L.). The IMAG (Inst. voor Mechanisme, Arbeid en Gebouwen) production planning system (Annevelink, 1992) optimized space and labor use in the greenhouse, while Udink ten Cate and Challa (1984) presented an hierarchical system for describing crop growth. Decision analysis has been used to supply crop nutrients to plants based on various ranges of solar irradiance and a plant response rule-base derived from an expert (Fynn and Fraser, 1993; Fynn et al., 1989). Gauthier (1992) developed an object-oriented platform that accommodates the design and operation of knowledge-based greenhouse environmental control systems. Another knowledge-based system determined the daily climatic setpoints for winter production of greenhouse tomato (Lycopersicon esculentum Mill.) while balancing conflicting goals, such as avoiding diseases, maintaining crop growth and development, and minimizing energy expenditures (Martin-Clouaire et al., 1993).

This paper discusses the interdependence and complexity of various greenhouse crop management factors and the role of an expert system in implementing an integrated strategy for cost-effective production.

Greenhouse crop management. Greenhouse crop management involves a complex hierarchy of factors that must be integrated for efficient and profitable crop production (Fig. 1). First-order factors directly affect the greenhouse crop; second-order factors directly affect the first-order factors and indirectly the crop, and so on. For example, diseases are directly influenced by management practices, the environment, chemical pesticides, biological control agents, vectors, and plant nutrition (Fig. 1). But these same factors may also affect the crop both directly and indirectly. A chemical pesticide, for example, can directly affect yield and quality because it is phytotoxic, but it indirectly enhances yield by controlling a pest. There must also be a feedback mechanism using both the grower's experience and information from sensors in the crop or in the plant-the so-called "speaking plant"- to modify the various pathways (Hashimoto et al., 1981; Udink ten Cate et al., 1978).

Cultural practices. Cultural operations, including cultivar selection, media preparation, sowing, transplanting, training, pruning, and planting and harvest scheduling, are important components within an overall crop management strategy.

Environment. Root-zone temperatures, day and night air temperatures, vapor pressure deficit (VPD; a measure of the difference in air moisture between the saturated and actual water vapor pressure at a specific temperature), $\mathrm{CO}_{2}$ concentration, and solar radiation are dynamically controlled throughout the cropping season to ensure optimal growing conditions and maximum productivity with minimum energy and other inputs.

Nutrition. Adequate, but not excessive, supplies of macro- and micronutrients, in proper balance with each other and at the correct $\mathrm{pH}$ and electrical conductivity (EC), are essential for healthy crop growth, particularly in soilless cultivation. Computer-controlled fertigation systems accurately dispense fertilizers and continually monitor water and fertilizer status to ensure their optimal delivery to the crop without waste to the environment (Papadopoulos and Liburdi, 1989). Fertigation requirements change as the crop matures and the season progresses, and errors or equipment failure can result in complete crop loss in just a few hours. Within limits, fertigation and environment can be manipulated to advance or retard crop development to meet forecast market conditions.

Pests. Insects and mites reduce crop yield and quality, but they can be controlled in several ways. Screened vents impede the entry of pests but at some cost to ventilation efficiency. Monitoring pest population levels with 


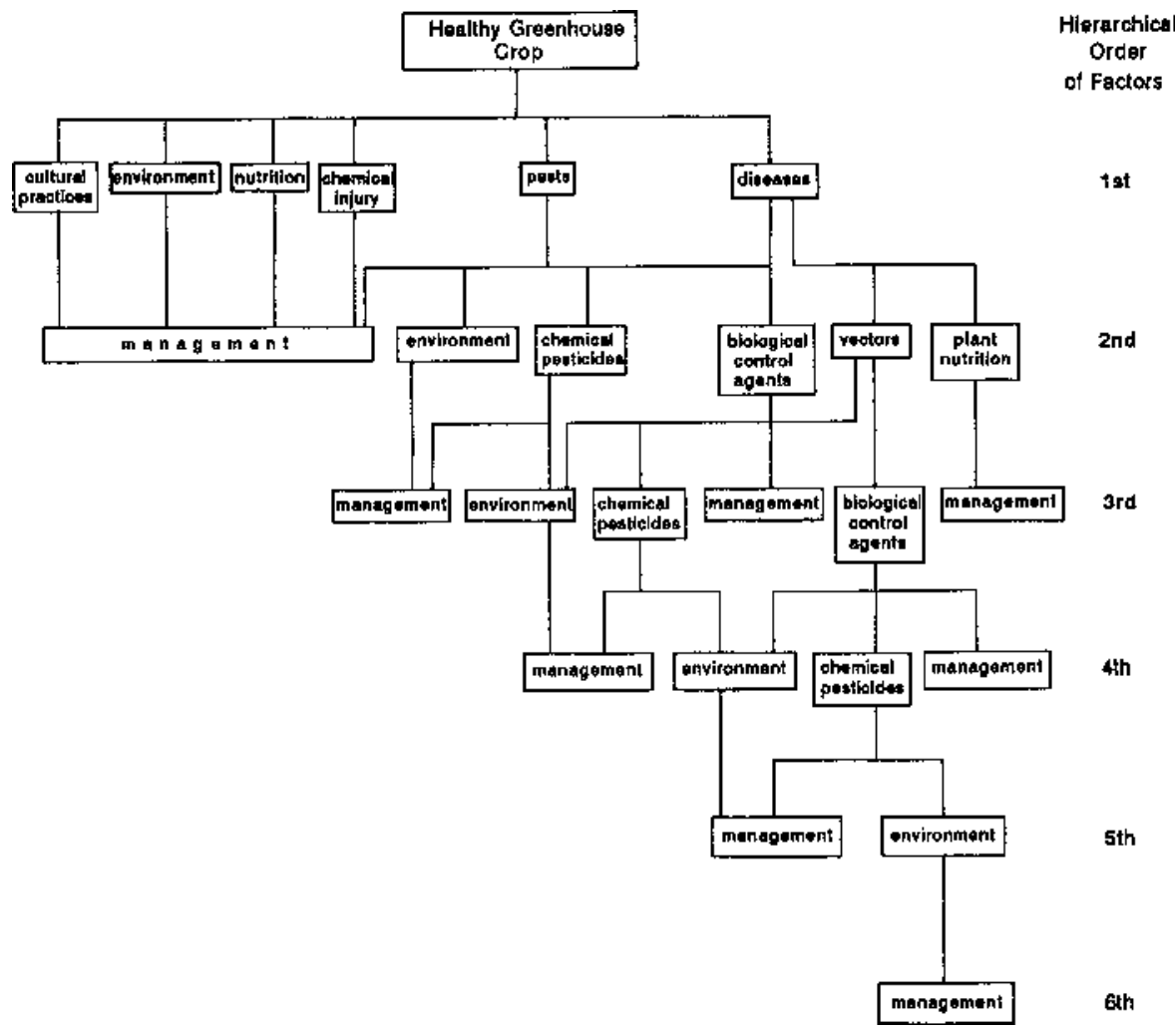

Fig. 1. Simplified hierarchy of factors affecting greenhouse plant production within an integrated crop production framework. Changes in any one factor can affect virtually all others, some beneficially and some adversely.

sticky traps predicts potential outbreaks of pests and allows for early and less costly control actions (Shipp et al., 1991). Greenhouse temperatures and VPDs affect pest activity and development. For example, the survival rate of the different stages of western flower thrips (Frankliniella occidentalis Pergande) decreases with increasing temperature and VPD (Shipp and Gillespie, 1993), and development time varies from 33.7 days at $15 \mathrm{C}$ to 13.4 days at 25C (Malais and Ravensberg, 1992). Environmental factors also affect predator/parasite $\times$ prey interactions of biological control agents. Kajita (1979) reported that extremes ( $31 \%$ and $100 \% \mathrm{RH})$ in humidity decreases the fecundity and longevity of Encarsia formosa (Gahan), a parasite of the greenhouse whitefly. Encarsia formosa provides effective control of greenhouse whitefly between $50 \%$ and $85 \%$ RH (Malais and Ravensberg, 1992). Time and rate of application, site of application, and initial pest and pathogen levels influence the effectiveness of biological control agents.

Chemical control strategies are also significantly affected by the greenhouse environment. The efficacy of pesticides that are sprayed is affected by temperature, which controls the speed of the toxic action on a specific biochemical substrate. Surface wetness, which controls pesticide distribution and redistribution, also affects pesticide efficacy (Hislop and Baines, 1980). Pesticidal action of fumigants is highly dependent on environmental factors. These relationships can now be simulated using a computer (Siebering and Leistra, 1979). As well, many chemicals applied to control pests or diseases can harm biological control agents, the degree of injury being influenced by environmental conditions.

Diseases. Many diseases caused by fungi, bacteria, nematodes, and viruses can be controlled by manipulating the crop and its environment (Jarvis, 1992). Most pathogens have very complex life cycles, components of which respond to the environment in different ways. For example, the gray mold fungus, Botrytis cinerea Pers.:Fr., produces the most conidia at $15 \mathrm{C}$, releasing them by a hygroscopic mechanism in conditions of rapidly changing VPD. These conidia usually infect the plant by means of a film of water. The conidia germinate optimally at $20 \mathrm{C}$, but the germ tubes elongate fastest at 30C. Overall, the optimum temperature for infection depends on the host, and ranges from 15 to 25C (Jarvis, 1977). Controlling the environment to avoid dew deposition and providing good ventilation helps prevent infection by $B$. cinerea and several other fungi.

Plant nutrition also influences diseases. Excess nutrients, especially $\mathrm{N}$, which produces susceptible, soft, vegetative growth, provide conditions favorable to fungi such as B. cinerea and to bacteria such as Pseudomonas spp. Other diseases, such as leaf blights, mainly affect plants weakened by heavy cropping or by mineral deficiencies (Engelhard, 1989).

In many cases, environmental and other data can be used to forecast infection and the development of epidemics so that preventive and remedial actions can be implemented in time. For example, Marois et al. (1988) and Yunis et al. (1990) have correlated the incidence and severity of grey mold on roses (Rosa hybrida) and cucumbers, respectively, with temperature, VPD, and duration of surface wetness for up to 5 weeks before harvest.

Biological control of fungi and bacteria with other fungi and bacteria is new, and success with these agents also depends on properly managing environmental conditions. For example, Stephanoascus spp. require VPD $<0.6 \mathrm{kPa}$ and an optimum 26C for effective powdery mildew control (Jarvis et al., 1989).

Plant viruses and some fungi and bacteria are spread from plant to plant by nematode or insect vectors, such as the greenhouse whitefly, Trialeurodes vaporariorum Westwood, which transmits the beet pseudo-yellows virus in cucumber and other crops. It is imperative to control these vectors (Jarvis, 1992).

Chemical injury. Crops can be damaged by inappropriate or excessive chemicals applied inside the greenhouse or outside with spray drifting in through doors and ventilators. Some fungicides and insecticides on their own reduce both yield and quality (de Waard et al., 1993; Griffiths, 1981; Regev, 1984), tending to negate their beneficial effects of disease and pest control. Calendar-based sprays applied at regular intervals over the growing season for pest and disease control are seldom, if ever, justified. Accurately forecasting outbreaks involves monitoring pertinent environmental variables using computerized climate-control systems and pest and pathogen population data obtained by various sampling methods, such as sticky traps and direct observations. Accurately timing pesticide applications will improve the effectiveness of chemical control and, thus, reduce the number of pesticide treatments applied to the crop.

The need for integrated crop management. Managing the complex greenhouse cropping system requires a multidisciplinary approach that integrates pest and disease protection strategies with routine cultural practices and environmental and fertigation regimes into a common decision-making process or "integrated crop management" (ICM) strategy. The accessibility of information is a formidable problem in itself for the grower, but the greatest problem with an ICM approach is reconciling the conflicting recommendations offered by individual experts. One example might be recommendation of a fungicide for a disease outbreak that is harmful to biological agents used to control a pest problem; another might be the recommendation of environmental conditions to promote the use of entomopathogens that can also result in disease outbreaks. Within the ICM approach, growers require expert knowledge in five key areas: crop production practices, crop disorder (disease, pest, and physiological) identification, disorder forecast, disorder prevention, and disorder control. Most of all, they need all conflicts resolved.

Expert system. Conflict resolution skills are necessary to reconcile conflicting recommendations and to plot the best and most profitable crop management strategy. Good growers can resolve most conflicts almost intuitively, with the aid of a reassuring technical database. Less-experienced growers rely heavily on experts; thus, it is necessary to 
provide these growers with all the necessary information to make a decision. An expert system can help both types of growers by assisting and reassuring them in their management decisions.

There are many obstacles to overcome in developing an expert system for ICM. Knowledge must be acquired and integrated from several experts. Above all, growers must understand the system and be willing to use it, so the language of the expert and the grower must be the same. By definition, an expert is a specialist in a narrow field of research or technological development who constantly relies on the expertise of others in closely related fields. Greenhouse disease experts, for example, usually speak only the same limited scientific language as colleagues in their research discipline, but they are responsible for digesting the expertise of others, including research and development literature, and translating this information into clear, nontechnical language that their fellow experts and the growers can understand. Thus, terms such as "lesion," "cornicle," and "siemens" have to be either avoided somehow or fully explained in text.

An expert system for ICM of greenhouse crops should allow for operation in two modes: continuous and discrete operation. With continuous operation, the expert system continuously monitors greenhouse environmental conditions, and any conditions that are adverse to cropping, or conducive to disease or pest outbreaks, are flagged. It recommends appropriate low-cost preventive actions, such as changing environmental settings or modifying fertilizer and water application rates. Also, on a daily basis, the expert system offers a schedule of management activities and conditions, including fertigation levels, interpretation of insect catches on sticky traps, and environmental setpoints for a crop growth stage and external weather. The discrete operation mode trouble-shoots specific crop problems. With grower input, the expert system diagnoses the problem and suggests appropriate preventive and remedial actions.

A conceptual model of an expert system for ICM of greenhouse cucumber is shown in Fig. 2. A module for each of the five key areas of required knowledge is included. Each of these modules consists of rules and facts, acquired from the experts, to solve problems in its key area. Arrows indicate where the results (output) from a module are used as input for another module. For example, the result obtained from the disorder identification module is required by the disorder control module and its output in turn (a control action or series of actions) is input to the conflict resolution module. This decision-making module must consider all actions from the disorder control, disorder prevention, and crop production modules; determine if there are any conflicting actions; resolve the conflicts; and determine the most appropriate and costeffective course of action. One of the considerations must always be "do nothing" so that growers can assess the consequences of taking

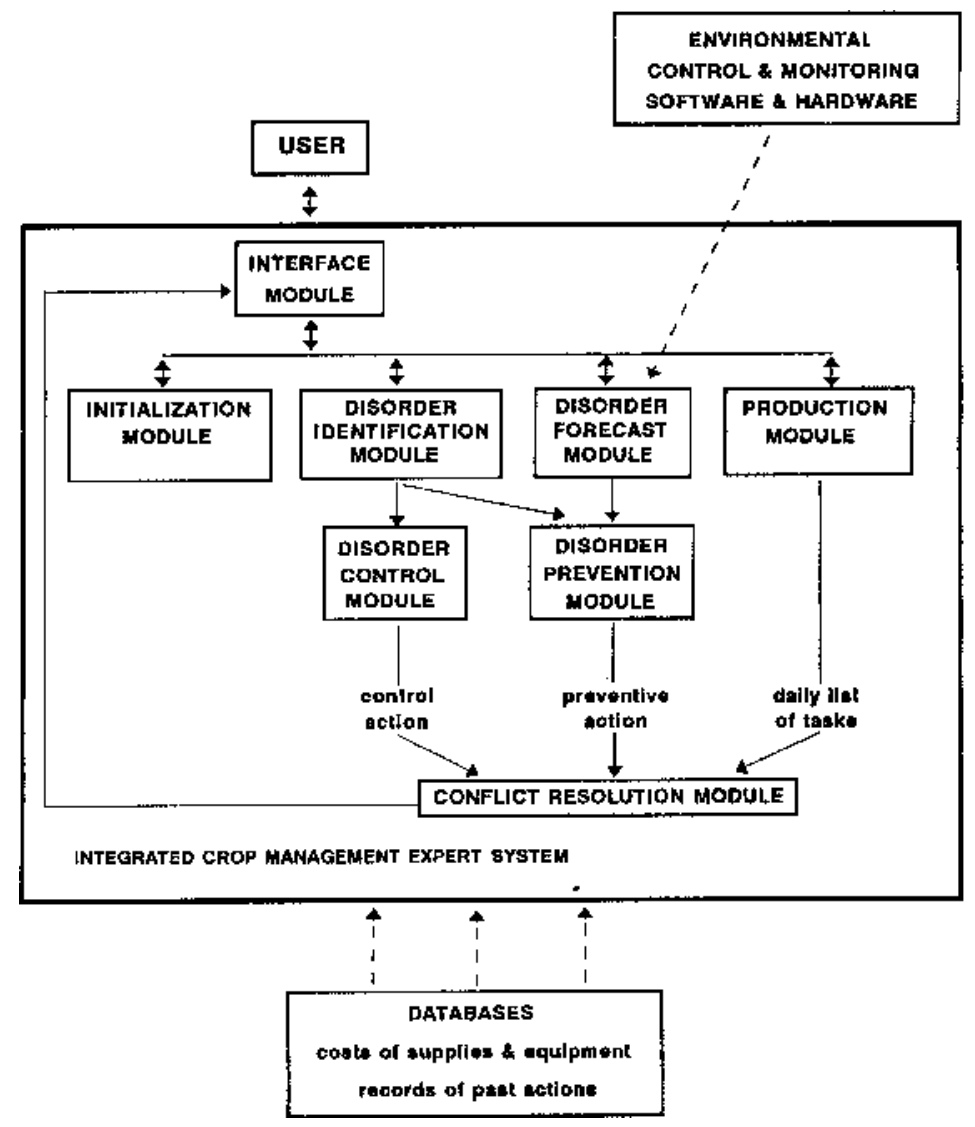

Fig. 2. Scheme of an expert system for integrated greenhouse crop management. no action. In addition, an interface module controls interactions between the user and expert modules, and an initialization module sets up and customizes the expert system for individual greenhouse operations. Databases provide the expert system with data, such as purchasing and labor costs, costs of remedial actions, and cropping history records.

The disorder forecasting module requires data from the existing greenhouse environmental control system. Temperature, VPD, solar radiation, and accumulated degree days are monitored continuously by the computer to identify conditions that could lead to a disease or pest outbreak. This information, combined with monitoring data of the population levels of disease and pest organisms, is used by the forecasting module to predict potential outbreaks.

A preliminary version of an expert system for greenhouse cucumber is being used to test the conceptual model. Experts from the Agriculture Canada Research Station, Harrow, Ont., and the extension service of the Ontario Ministry of Agriculture, Food, and Rural Affairs are providing the knowledge for the program (Jarvis et al., 1993; Shipp et al., 1993). The expert system requires a 386 personal computer and Microsoft Windows (Microsoft Corp., Redmond, Wash.) for operation. Version 1 of the interface, disorder identification, disorder control, and disorder prevention modules is completed and is being tested in the field by extension personnel when they visit greenhouses. The expert system can identify and recommend control and preventive actions for 33 diseases, 22 physiological disorders, and 15 pests of greenhouse cucumber. The remaining modules are currently under development and scheduled for completion by the end of 1995 . When completed, the expert system will combine the knowledge of a plant disease expert, a greenhouse pest expert, and a plant physiology expert. Grower acceptance is of prime importance (Beck et al., 1993) and a committee of experienced growers is reviewing our system continually during development and providing recommendations for improvement. Growers have found the system easy to use, and extension personnel consider it to be a valuable educational tool.

\section{Literature Cited}

Annevelink, E. 1992. Operational planning in horticulture: Optimal space allocation in pot-plant nurseries using heuristic techniques. J. Agr. Eng. Res. 51:167-177.

Barrett, J.R. and D.D. Jones. 1989. Knowledge engineering in agriculture. Amer. Soc. Agr.Eng. Monogr. 8, St. Joseph, Mich.

Beck, N.G., N.A. Martin, and P.J. Workman. 1993. IPM for greenhouse crops in New Zealand: Grower acceptance. Intl. Organization Biol. \& Integrated Control Noxious Animals \& Plants/ West Palaearctic Reg. Sect. Bul. 16(2):1-4.

de Waard, M.A., S.G. Georgopoulos, D.W. Hollomon, H. Ishii, P. Leroux, N.N. Ragsdale, and F.J. Schwinn. 1993. Chemical control of plant diseases: Problems and prospects. Ann. Rev. Phytopathol. 31:403-421.

Engelhard, A. W. 1989. Soilborne plant pathogens: Management of diseases with macro- and 
microelements. APS Press, St. Paul, Minn.

Fynn, R.P. and J.M. Fraser. 1993. Learning from data: The beta distribution and probabilities of solar irradiance ranges. AI Applications 7(4):4557.

Fynn, R.P., W.L. Roller, and H.M. Keener. 1989. A decision model for nutrient management in controlled environment agriculture. Agr. Systems 31:35-53.

Gauthier, L. 1992. GX: A small talk-based platform for greenhouse environmental control. Trans. Amer. Soc. Agr. Eng. 35(6):2003-2020.

Gohler, A. 1989. Expert system cucumber. Acta Hort. 248:453-457.

Griffiths, E. 1981. Iatrogenic plant diseases. Ann. Rev. Phytopathol. 19:69-82.

Hashimoto, Y., T. Morimoto, and S. Funada. 1981. Computer processing of speaking plant for climate control and computer aided plantation (computer aided cultivation). Acta Hort. 115:317-325.

Hislop, E.C. and C.R. Baines. 1980. An analysis of some factors affecting the protection of foliage by fungicides, p. 23-33. In: J.O. Walker (ed.). Spraying systems for 1980s. Monogr. 24. BPCP Publications, Croydon, England.

Jarvis, W.R. 1977. Botryotinia and Botrytis species: Taxonomy, physiology and pathogenicity. Can. Dept. Agr. Monogr. 15.

Jarvis, W.R. 1992. Managing disease in greenhouse crops. APS Press, St. Paul, Minn.

Jarvis, W.R., N.D. Clarke, J.L. Shipp, and A.P. Papadopoulos. 1993. An expert system for inte- grated management of greenhouse cucumbers. 6th Intl. Congr. Plant Pathol., 28 July-8 Aug. 1993, Montreal. Abstr. 4.1.1.

Jarvis, W.R., L.A. Shaw, and J.A. Traquair. 1989. Effect of environmental factors on the antagonism of cucumber powdery mildew by Stephanoascus flocculosus and S. rugulosus. Mycol. Res. 92:162-165.

Kajita, H. 1979. Effects of temperature and humidity on fecundity and longevity of Encarsia formosa Gahan, An introduced parasite of the greenhouse whitefly, Trialeurodes vaporariorum (Westwood). Proc. Assn. Plant Prot. Kyushu 25:112-113.

Malais, M. and W.J. Ravensberg. 1992. Knowing and recognizing: The biology of glasshouse pests and their natural enemies. Koppert B.V., Berkel en Rodenrijs, Netherlands.

Marois, J.J., J.C. Redmond, and J. MacDonald. 1988. Quantification of the impact of environment on the susceptibility of Rosa hybrida flowers to Botrytis cinerea. J. Amer. Soc. Hort. Sci. 113:842-845.

Martin-Clouaire, R., K. Kovats, and M. Cros. 1993. Determination of greenhouse climate setpoints by SERRISTE: The approach and its objectoriented implementation. AI Applications 7(1):1-15.

Papadopoulos, A.P. and N. Liburdi. 1989. The "Harrow Fertigation Manager?"-A computerized multifertilizer injector. Acta Hort. 260:255-265.

Regev, U. 1984. An economic analysis of man's addition to pesticides, p. 441-453. In: G.R.
Conway (ed.). Pest and pathogen control strategies: Strategic, tactical, and policy models. Wiley \& Sons, Chicester, U.K.

Shipp, J.L., G.J. Boland, and L.A. Shaw. 1991 Integrated pest management of diseases and arthropod pests of greenhouse vegetables in Ontario: Current status and future possibilities. Can. J. Plant Sci. 71:887-914.

Shipp, J.L., N.D. Clarke, W.R. Jarvis, and A.P. Papadopoulos. 1993. Expert system for integrated crop management of greenhouse cucumber. Intl. Org. Biol. Integrated Control Noxious Animals Plants/West Palaearctic Reg. Sect. Bul. 16(2):149-152.

Shipp, J.L. and T.J. Gillespie. 1993. Influence of temperature and water vapour pressure deficit on survival of Frankliniella occidentalis (Thysanoptera: Thripidae). Environ. Entomol. 22:726-732.

Siebering, H. and M. Leistra. 1979. Computer simulation of fumigant behaviour in soil, p. 135-161. In: D. Mulder (ed.). Soil disinfection. Elsevier, Amsterdam.

Udink ten Cate, A.J., G.P.A. Bot, and J.J. van Dixhorn. 1978. Computer control of greenhouse climates. Acta Hort. 87:263-272.

Udink ten Cate, A.J. and H. Challa. 1984. On optimal control of the crop growth system. Acta Hort. 148:267-276.

Yunis, H., Y. Elad, and Y. Mahrer. 1990. The effect of air temperature, relative humidity and canopy wetness on grey mold of cucumbers in unheated greenhouses. Phytoparasitica 18:203-215. 